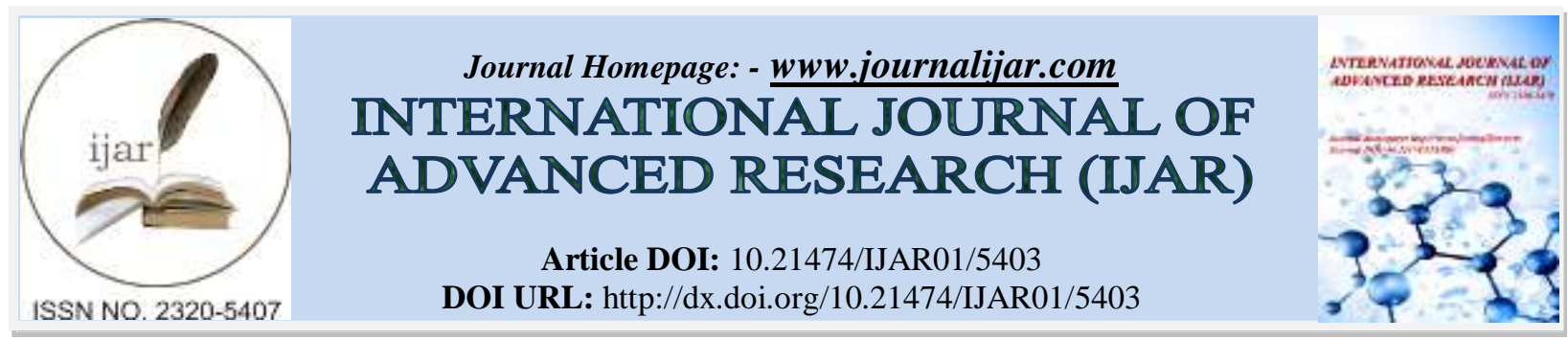

RESEARCH ARTICLE

\title{
EVALUATION OF IN VIVO WOUND HEALING ACTIVITY OF THE EXTRACT AND OLEUROPEIN FROM MORINDA TINCTORIA ROXB. (RUBIACEAE)- A TRADITIONAL MEDICINAL PLANT.
}

A. Muhamad Ibrahim, *A. Nagarajan and Muhammed Majeed.

Department of Phytochemistry, Sami Labs Ltd, Peenya Industrial Area, Bangalore, India.

\section{Manuscript Info}

Manuscript History

Received: 11 July 2017

Final Accepted: 13 August 2017

Published: September 2017

Key words:-

Oleuropein, Morinda tinctoria, Iridoid,

Wound healing activity.

\section{Abstract}

The wound healing effects of ethanolic extracts of leaves and fruits of Morinda tinctoria as well as of the minor polyphenolic constituents iridoid, Oleuropein against the incision and excision wounds on Wistar albino rats was examined and elaborated in this study. The dried fruits and leaves of Morinda tinctoria were extracted with ethanol, dried in vacuum, grinded to form a powder and used in experiment (MTFE and MTLE). In vivo experiments were designed in six groups of Wistar albino rats consisting of group I (control), group II (treated with $15 \%$ of MTFE), group III (treated with $30 \%$ MTFE), group IV ( treated with $1.5 \%$ pure iridoid, Oleuropein), group V (treated with $3 \%$ pure iridoid, Oleuropein) and group VI (treated with standard drug, Soframycin) for 0-15 days. The present study is the first report to quantify oleuropein, not only in leaves, but also in fruits. It was observed that the occurrence of oleuropein is much higher in MTFE $(0.81 \%)$ compared to MTLE $(0.12 \%)$. Quick and effective incision and excision wound healing was observed in group III treated with 30\% MTFE than with respect to any other groups. Analyses were done on tensile strength of skin, granuloma weight, platelet derived growth factor (PDGF), Tumour necrosis factor (TNF) alpha, hydroxyproline, hexosamine in granulated tissue, enzymes such as LPO, GSH, SOD, CAT, GPX, serum ascorbic acid levels and nucleic acid contents. This result demonstrates that oleuropein alone is not effective and the components present in MTFE together with oleuropein might have exhibited synergistic action in wound healing.

Copy Right, IJAR, 2017,. All rights reserved.

\section{Introduction:-}

The genus Morinda (Family Rubiaceae) is common in many tropical countries and is considered as an important conventional folk medicine. Although many species of Morinda are available in India, the most important species is Morinda tinctoria (MT) (Fig.1) commonly known as Indian mulberry.

In Indian traditional systems of medicine, MT leaves are internally used as astringent and externally to relieve pain associated with gout and rheumatism. Fruits are mashed and applied to boils (Pal et al., 1998). The juice of the leaves is internally given to facilitate digestion and it act as a febrifuge (Nadkarni., 1998).

Corresponding Author:- A. Nagarajan.

Address:- Department of Phytochemistry, Sami Labs Ltd, Peenya Industrial Area, Bangalore, India. 
The natural antioxidant content was found to be high in the fruit extracts of MT compared to Morinda citrifolia $(M C)$. The fruit extracts of $M C$ and $M T$ have also been shown to have effective anti-diabetic activity in alloxan induced experimental rats. This activity was more pronounced with $M C$ than with $M T$. The fruit extract of both the plants showed good plant growth promoting activity in rice and green gram. However, this activity was more pronounced with $M$. citrifolia than with M. Tinctoria (Mathivanan et al., 2006). In addition, the Morinda tinctoria has antimicrobial, anticonvulsant, cytoprotective and antioxidant effects (Jayasinghe et al., 2002; Kumarasan et al., 2009; Deepti et al., 2012). The phytochemistry of this plant has been studied by Kolli et al.,2015 and they have reported the presence of cyanarin and oleuropein from the leaves of this plant. Their main focus was on antioxidant activity by using different assays.

This article is a further contribution to the phytochemistry of this plant (extracts of both leaves and fruits) with additional information on oleuropein (particularly quantification) as well as on the wound healing activity. In the present study, the crude extract and pure oleuropein samples were evaluated for wound healing activity for the first time from this plant.

\section{Materials And Methods:-}

\section{Collection of Plant materials:-}

The plant specimens (leaves and fruits) were collected from Kallakurichi, Villupuram district, Tamil Nadu, India during June 2013. The voucher specimen (Ref.RRCBI-AP4665) was deposited at National Ayurveda Dietetics Research Institute (NADRI), Bangalore -560 011, India. The taxonomic identification was done by Dr. B.N.Sridhar, Assistant Director, (NADRI), Bangalore -560 011. The fresh leaves and fruits were washed with tap water, rinsed with distilled water, air-dried for an hour, washed and rinsed once again thoroughly in distilled water and shadedried in open air. The dried leaves were then pulverized and the coarse powder obtained was sieved in 20 mesh size sieve.

$500 \mathrm{~g}$ of the powdered $M T$ fruits and $M T$ leaves were separately extracted with three volume ethanol in a Soxhlet apparatus at $55^{\circ} \mathrm{C}$ for $3 \mathrm{~h}$. The extraction was repeated for three more times. The extracts of leaves (MTLE) and fruits (MTFE) were filtered through Whatman No. 1 filter paper, collected separately, concentrated, dried under vacuum and the yields recorded. The extracts obtained were used for phytochemical analysis and for studying wound healing activities.

\section{Isolation of oleuropein:-}

Ethanol extracts of Morinda tinctoria leaves and fruits were kept chilling at $5^{\circ}-10^{\circ} \mathrm{C}$ for $5 \mathrm{hrs}$. The separated oleanolic acid is filtered, added water to the filtrate and concentrated under vacuum to remove the ethanol. Then the extract was partitioned with two volumes of chloroform (three times).

TLC investigation (Solvent system: Hexane: Ethyl acetate: Methanol $(7: 3: 1(\mathrm{v} / \mathrm{v}))$ revealed the presence of oleuropein in the aqueous layer. Again, the aqueous layer was partitioned with equal volume of ethyl acetate by three times. The ethyl acetate layer was collected, pooled and concentrated completely in vacuo. Concentrated Ethyl acetate layer was subjected to column chromatography using Silica Gel (60-120 mesh) prepacked with ethyl acetate. This was eluted with ethyl acetate alone and the pure molecule was isolated and characterized. The structures of the isolated compounds were confirmed by using various spectral instruments like LCMS, NMR $\left({ }^{1} \mathrm{H}\right.$ and ${ }^{13} \mathrm{C}$ NMR).

\section{HPTLC finger print analysis:-}

HPTLC chromatography is an advanced technique which is used to detect the phytochemicals present in two different wavelengths ( $254 \mathrm{~nm}$ and $366 \mathrm{~nm}$ ). CAMAG HPTLC System, equipped with a Linomat V with Camag 100 $\mu \mathrm{L}$ syringe sample applicator, a twin chamber tank, a model Camag twin trough glass chamber $(20 \mathrm{~cm} \times 10 \mathrm{~cm})$ and a thin layer chromatography (TLC) scanner and Camag TLC scanner 3 software WinCats 4.3.1 version were used in the study. $10 \mu \mathrm{l}$ of MTFE extracts and $5 \mu \mathrm{l}$ of Reference standard oleuropein $(1 \mu \mathrm{g} / \mu \mathrm{l})$ were applied to tracks in TLC aluminium sheets $(10 \mathrm{~cm} \times 10 \mathrm{~cm})$ of silica gel $\mathrm{G}_{60} \mathrm{~F} 254$. The plates were developed up to $90 \mathrm{~mm}$ after chamber saturation conditions. After air drying the solvent, the plates were scanned using scanner 3 at $254 \mathrm{~nm}$ wavelengths in absorbance mode.

HPTLC fingerprinting profile is attempted using different mobile phases for the separation of ethanolic extracts of MTLE and MTFE along with the isolated compound, oleuropein. Screening was done using two different solvent systems: ethyl acetate: methanol: water: glacial acetic acid (80:12:6:2) and Hexane: ethyl acetate: methanol (7:3:1). 
It was found that the suitable mobile phase is hexane: ethyl acetate: methanol (7:3:1); the application volume at 10 $\mu \mathrm{L}$ each.

\section{HPLC Analysis:-}

$100 \mathrm{mg}$ of the MTFE ethanol extract was dissolved in methanol and diluted to $100 \mathrm{~mL}$ to obtain a concentration of $2.5 \mathrm{mg} / \mathrm{ml}$. The prepared solution was passed through a filter of pore size $0.45 \mu \mathrm{m}$ to acquire a clear solution. Standard oleuropein was prepared in the same manner as like sample solution to obtain concentrations $100 \mu \mathrm{g} / \mathrm{mL}$ of oleuropein. The MTFE and the standard solution were subjected to HPLC separately. A gradient HPLC (Shimadzu HPLC Class VP series) with two LC- 10 AT VP pumps (Shimadzu), UV visible detector SPD-10A, an SCL-10A VP system controller (Shimadzu), a reverse phase Luna ${ }^{\circledR} 5 \mu \mathrm{m} \mathrm{C18} \mathrm{(2)} \mathrm{Phenomenex} \mathrm{ODS} \mathrm{column} \mathrm{(250} \mathrm{mm} \mathrm{X} \mathrm{4.} 6$ $\mathrm{mm}$ ) was used. The mobile phase constitutes $2 \%$ acetic acid in water (Mobile Phase A) and $100 \%$ acetonitrile (Mobile Phase B) which were filtered through a $0.2 \mu \mathrm{m}$ membrane filters before use and pumped from the solvent reservoir at a flow rate of $1.5 \mathrm{ml} / \mathrm{min}$. About $20 \mu \mathrm{L}$ of the respective sample was injected by using a Rheodyne syringe (Model 7202, Hamilton) and the HPLC peaks were observed at $278 \mathrm{~nm}$. Further analysis was also carried out to compare the HPLC chromatogram of MTLE \& MTFE ethanol extract against standard compound oleuropein.

\section{In -Vivo Studies On Wound Healing:- \\ Selection of experimental rats:-}

Wistar albino rats of both sexes weighing 250-280 g were used for the study. The animals were kept in standard condition. The room temperature was maintained at $22^{0} \pm 2^{\circ} \mathrm{C}$ with food and water adlibitum. The animals were transferred to the lab at least $2 \mathrm{~h}$ before the start of the experiments. The protocols for conducting the wound healing activities in rats were approved by Institutional Animal Ethics Committee. (IAEC) (Reg.No: SAC/IAEC/BC/2015/Ph.D-002 dated 14.07.2015).

\section{Wound Incision in a rat:-}

Incision wound was created under light ether anesthesia; two paraventral incisions of $6 \mathrm{~cm}$ were made through the entire thickness of skin on either side of vertebral column with the help of a sharp blade. After the incision was made the parted skin was kept together and sutured with nylon thread by $0.5 \mathrm{~cm}$ apart. Surgical thread (No.000) and curved needle of No.11 were used for suturing. The continuous thread of both wound edges was tightened for good adoption of wounds. Breaking strength or tensile strength represents the promotion of wound healing. (Rao et al., 2000) (After creating the wounds, all the animals in the groups were kept separately for 0-3 days).

\section{Wound excision in a rat:-}

An excision wound was made on the dorsal side of rats. The dorsal side of rats was shaved with a razor blade. Excision wound of size $2.5 \mathrm{~cm}^{2}$ areas of skin in length, $0.2 \mathrm{~cm}^{2}$ in depth was created by using surgical scissors. Haemostasis was achieved by blotting the wound with cotton swab soaked in normal saline. The wound was left undressed to the open environment. (After creating the wounds, all the animals in the groups were kept separately for 0-3 days).

\section{Experimental design in Incision and Excision wounding:-}

Six groups of Wistar albino rats were used as controls and the wounds were treated with crude extract and pure drug. Group I :Normal incision/ excision wounded animals without treatment

Group II $\quad$ :Normal incision/excision wounded animals treated with 15\% of MTFE.

Group III : :Normal incision/excision wounded animals treated with 30\% of MTFE.

Group IV :Normal incision/excision wounded animals treated with $1.5 \%$ of oleuropein. Isolated oleuropein from the MTFE was used as an ointment base.

Group V : :Normal incision/excision wounded animals treated with 3\% oleuropein.

Group VI : : Normal incision/excision wounded animals treated with standard drug soframycin ointment.

\section{Analysis of wound contraction:-}

The percentage of wound reduction was determined by the reduction in wound size. The wound size was measured regularly by tracing wound site with trace paper and measured graphically. After incision ( 0 to 15 days), the remaining wound was measured by using vernier calliper. The surface area of the wound was measured while conducting the experiment. The reduction of wound size was checked from the initial and final area of the wound. 
The standard deviations and mean deviations were given in $\mathrm{cm}$. The percentage of wound reduction $=\frac{\text { Area of the initial wound }- \text { Area of the actual wound } X 100}{\text { Area of the initial wound }}$

The Wistar albino rats were sacrificed after 15 days of study, after taking the blood samples.

Analysis of tensile strength:-

Wound breaking strength (WBS) was measured on 15th post-wounding day. The breaking strength was measured with a manually operated instrument in terms of weight (Saha et al., 1997; Lee 1968).

\section{Biochemical estimations:-}

The following biochemical measurements/estimations were made on the experimental rats and control rats: (i) Tensile Strength of skin (ii) Analysis of granuloma weight, (iii) Analysis of platelet derived growth factor, (iv) Analysis of TNF alpha, (v) Analysis of hydroxyproline (Woessner., 1961) (vi) Analysis of hexosamine in granulated tissue (Wagner., 1979), (vii) Analysis of enzymes in experimental animals, (viii) Analysis of the serum Ascorbic acid levels in experimental animals, (ix) Analysis of nucleic acid content by diphenylamine reaction (Giles et al., 1965), (x) Analysis of RNA content (Yoichi Endo., 1970).

\section{Statistical analysis:-}

All values are mentioned as the mean \pm SD. Animal group comparison was made through used one-way analysis of variance (ANOVA) test followed by multiple range tests employing SPSS 11.0 for windows. P $<0.05$ is considered statistically significant.

\section{Results and Discussion:-}

Characterization of the compound:-

The structure characterization of the isolated compound (Fig.2), a colourless powder was carried out by spectroscopic techniques. The molecular weight of the compound was obtained by Liquid Chromotography- Mass Spectrometry (LC-MS). The mass spectrum showed parent molecular ion $\mathrm{m} / \mathrm{z}$ at $539.06[(\mathrm{M}+1)$ at $\mathrm{m} / \mathrm{z} 540.51]$ (Fig.3) which confirm the assignment of molecular formula of $\mathrm{C}_{25} \mathrm{H}_{32} \mathrm{O}_{13} \cdot{ }^{1} \mathrm{H}$ and ${ }^{13} \mathrm{C}$ NMR spectra of compound recorded were in agreement with the reported values (Kadowaki et al., 2003). Based on the NMR spectroscopic data (Figs. 4 \& 5) obtained the structure of the compound was confirmed as Oleuropein. In 2015, Arunachalam et al., investigated the qualitative and quantitative screening of phytochemicals; they did characterization by HPTLC finger print analysis, HPLC and GC MS substantiation for the presence of scopoletin and rutin in methanolic leaf extract of Morinda tinctoria Roxb. But, oleuropein was not reported in this plant by them. However, in 2015, Kolli et al., reported the presence of oleuropein as a polyphenolic iridoid from the methanol extract of the leaves and their anti oxidant properties. However they have not quantified the amount of oleuropein in that extract. Therefore the present study is the first report on quantification of oleuropein not only in leaves, but also in fruits. Oleuropein obtained by us has a molecular weight of $540.51 \mathrm{~g} / \mathrm{mol}$ and molecular formula of $\mathrm{C}_{25} \mathrm{H}_{32} \mathrm{O}_{13}$ and we are first to report the quantification of oleuropein content from this plant as below.

The quantitative analysis is performed in both MTFE and MTLE and the results obtained are in Fig 6 \& 7. Oleuropein content was calculated by HPLC analysis. The standard oleuropein was eluted at Rt 15.0 min, and our samples eluted more or less the same RT at $14.99 \mathrm{~min}$. The oleuropein content in dried MTLE is $0.12 \%$ (w/w) and in MTFE $0.81 \%(\mathrm{w} / \mathrm{w})$.

\section{HPTLC Fingerprinting Profile:-}

Further our HPTLC results show (Fig. 8 \& 9) that the calibration curve of the oleuropein standard was linear; the correlation coefficient value $\left(\mathrm{R}^{2}\right)$ was 0.99 which indicates that there is good linearity between the area of the peaks and concentration. The obtained $\mathrm{R}_{\mathrm{f}}$ values from the chromatogram harmonized well with reference standard oleuropein in the peak display at $5 \mathrm{uL}$ applied volume. From fig. 8, it is further observed that, $\mathrm{R}_{\mathrm{f}} 0.25$ confirmed the presence of Oleuropein. MTFE fingerprinting also confirms the presence of oleuropein against the standard Chromatogram. 


\section{Biological Activity:-} Acute Toxicity study:-

The extract of MT was studied for acute toxicity and was found to be safe and there was no mortality upto the dose of $2000 \mathrm{mg} / \mathrm{kg}$, b.w in rats (Sait et al., 2014)

\section{Wound healing activity:-}

We investigated the wound healing properties of MTFE and the pure oleuropein in Wistar albino rats. Our studies showed an improved rate of wound contraction and reduction in healing time in animals treated with ointment containing MTFE in both excision and incision wounds (Fig. 10\&11).

$30 \%$ MTFE was found to be the most effective and quickest when compared to either 15\% MTFE or other concentrations of oleuropein $(1.5 \% \& 3 \%)$ in both types of wounds. The wound healing rate of this fruit extract was almost nearer to that of the standard drug, soframycin. A similar result was observed with the chloroform extract of fruit of this species (Mathivanan et al., 2006). They obtained about $93 \%$ and $100 \%$ wound healing after 15 days at $10 \mathrm{mg}$ per $\mathrm{mL}$ and $20 \mathrm{mg}$ per $\mathrm{mL}$ extract concentration respectively. It appears that the chloroform extract of fruit appears to be more effective than the ethanolic extract the present authors studied. This is the first work where in the effect of major component of Morinda tinctoria, oleuropein is experimented with respect to its effect on wound healing potential. However it is interesting to record that, pure oleuropein at the percentages of $1.5 \%$ and $3 \%$ is not as effective as that of MTFE. This strongly indicates that, other components present in MTFE are also involved in wound healing in addition to oleuropein in a synergistic way.

Wound healing is a complicated process and involves several physiological and structural changes beginning with wound closure, repair and replacing of damaged tissues with new tissue formation. This complexity can be better understood by studying tensile strength (Swamy et al., 2006); tensile strength indirectly indicates concentration and stabilisation of collagen fibres (Stadelmann et al., 1998) which forms the muscle tissue during wound healing. Results of studies made on tensile strength values are significant. ( $p<0.001)$. Here again, MTFE at $30 \%$ concentration promoted wound healing with greater tensile strength of skin than other treatments and was fairly nearer to soframycin treatment. ANNOVA test clearly indicates this significance of the values $(\mathrm{p}<0.001)$ obtained and presented in this Table No.1 (Annexure A).

Several biochemical parameters were studied in the animals subjected to wound healing in order to understand the biochemical changes associated with wounding and wound healing. The results of these studies are presented in Tables 1 to 14 as a supplementary data (Annexure A). Higher granuloma weights are associated with 30\% MTFE extract and soframycin. This indicates that these two are superior to other treatments in wound healing and the results obtained are statistically significant $(\mathrm{p}<0.001)$.

In incision wound study, MTFE showed an increase in breaking strength which may be due to the increase in collagen concentration and stabilization of the fibres (Udupa et al., 1995). The collagen molecules synthesized are laid down at the wound site and become cross-linked to form fibres. Wound strength is acquired from both remodeling of collagen and the formation of stable intra- and intermolecular cross links. MTFE showed greater breaking strength which may be due to increased collagen synthesis. In excision wound, MTFE showed faster healing compared with control group. The faster wound contraction by MTFE may be due to stimulation of interleukin-8, an inflammatory $\alpha$-chemokine which affects the function and recruitment of various inflammatory cells, fibroblasts and keratinocytes, and may increase the gap junctional intracellular communication in fibroblasts, and induces a more rapid maturation of granulation tissue (Moyer et al., 2002).

The level of Platelet derived growth factor (PDGF) is a very important factor in regulating cell growth and division. Since wound healing involves cell growth, cell division and cell differentiation, PDGF assumes great importance in wound healing (Pierce et al., 1991). The results of PDGF assay in different treatment are given in Annexure A. It is evident from this table that the level of PDGF in control wounds is the minimum among values observed while all other treatments (except soframycin) enhanced the level of PDGF but, showed almost the same level. This implies that, treatments enhance PDGF but this alone is not enough for better and quicker wound healing; additional factors may be involved.

The inflammatory phase in wound healing is considered to be a preparatory process for the formation of new tissue. A monocyte-derived cytokine, tumor necrosis factor-alpha (TNF-alpha), is a highly conserved molecule that is 
known to play a major role in the pathogenesis. TNF-alpha may have either a beneficial or detrimental role in wound healing (Rapala, K. 1996). The results of TNF - alpha assay made by us in different treatment are given in table 6. It is obvious from this table that the level of TNF - alpha in control wounds is more when compared to values observed in other treatments against the soframycin. It is also very significant $(\mathrm{p}<0.001)$ to note that TNF alpha level is the least in 30\% MTFE treated rats; probably here wound healing proceeds without much inflammation of wounded area.

The hydroxyproline content in rat treated with ointment containing oleuropein $1.5 \%$ was noteworthy and was more or less comparable to the control. Insignificant wound healing activity of the untreated rat was further witnessed by its lesser hydroxyproline content. Higher hydroxyproline content in 30\% MTFE might be attributed to improvement of the proliferation and migration of fibroblasts and collagen deposition (Hayouni et al., 2011). Since Hydroxyproline binds to protein to form a Hydroxyproline rich proteins under stress conditions, the wound healing probably involves these proteins and promotes faster healing as well as to help the animal to bear this stress. This is also supported by the high level of hydroxyproline observed in soframycin treated rats.

Hexosamine HXA content was significantly increased in MTFE treated group by $192 \%$ compared to the control group. ( $\mathrm{p}<0.001$ ). The results with MTFE were comparable with Soframycin drug.

Lipid peroxidation (LPO) is the process in which free radicals "steal" electrons from the lipids in cell membranes, causing cell damage. The end products of lipid peroxidation are reactive aldehydes, such as malondialdehyde (MDA). The major bioactive marker of lipid peroxidation, due to its numerous biological activities resembling activities of reactive oxygen species.

Lipid peroxidation is an important pathophysiological event in several diseases (Chigurupathi et al., 2013). MDA from lipid peroxidation can interact with DNA bases and induce mutagenic lesions. In 2016, Gonçalves, R. V. et al. and In 2006, Pratibha et al. showed that activated oxygen species can stimulate cellular activities such as enzyme inactivation, DNA strand cleavage and membrane lipid peroxidation, which are harmful to normal cells. Lipid peroxidation probably results in disposing of the necrotic cells near in the wounded area.

Glutathione (GSH) enzyme in granulated tissue is used in metabolic and biochemical reactions such as DNA synthesis and repair, protein synthesis, prostaglandin synthesis, amino acid transport, and enzyme activation. Thus, every system in the body can be affected by the state of the glutathione system, especially the immune system, the nervous system, the gastrointestinal system, and the lungs. GSH has a vital function in wound healing through the control gated channels in cell membranes. Glutathione (GSH) participates in leukotriene synthesis and is a cofactor for the enzyme glutathione peroxidase. Although the probable role of GSH in wound healing is not very clear, the fact that its higher level in MTFE (30\%) and soframycin treated animals indicated its probable role in better healing process.

Superoxide dismutase (SOD) has powerful anti-inflammatory activity. For example, SOD is a highly effective experimental treatment of chronic inflammation in colitis. Treatment with SOD decreases reactive oxygen species generation and oxidative stress and thus, inhibits endothelial activation. Therefore, such antioxidants may be important new therapies for the treatment of inflammatory bowel disease (Segui et al., 2004). The higher levels of SOD in 30\% MTFE and soframycin treated wounds support the above statement.

Chloramphenicol acetyl transferase (CAT) is a bacterial enzyme that detoxifies the antibiotic chloramphenicol and is responsible for chloramphenicol resistance in bacteria. This enzyme covalently attaches an acetyl group from acetylCoA to chloramphenicol, which prevents chloramphenicol from binding to ribosomes A histidine residue, located in the C-terminal section of the enzyme, plays a central role in its catalytic mechanism. CAT activity is determined by looking for the acetylated forms of chloramphenicol, which have a significantly increased migration rate as compared to the unacetylated form (Gorman et al., 1982). Higher levels of this enzyme activity in $30 \%$ MTFE and soframycin treated animals indicates the high anti oxidant activities in these treatments.

Glutathione peroxidise (GPX) is an antioxidant enzyme. GPX functions in the scavenging and inactivating of hydrogen and lipid peroxides, thereby protecting the body against oxidative stress. In fact, it is one of the most important antioxidant enzymes in humans (Ran et al., 2007). High levels of this enzyme in Group III and Group VI animals indicate its importance as a strong antioxidant. It can be concluding that a level of serum ascorbic acid in experimental animals shows significant improvement. 
Along with RNA and proteins, DNA forms one of the three major macromolecules that are essential for all known forms of life. MTFE extracts $(30 \%)$ and soframycin show a significantly higher DNA content compared to the control and hence it can be assumed that there is a greater amount of DNA synthesis needed for new cells and for repairing DNA of existing cells.

MTFE extracts (30\%) and soframycin treated rats show significant levels of RNA when compared to the control group. Greater RNA synthesis is needed for enhanced levels of transcription and translation activities in the cells near the wound.

\section{Conclusion:-}

Many studies have been done in the past to test the efficacy of the plant extracts on wound healing in animals. However, in several of these studies crude extracts of plant parts using solvent such as ethanol, chloroform etc. have alone been used. This is true of the two studies (Mathivanan et al.,2006 and Kolli et al., 2015 made with Morinda tinctoria. Although Morinda tinctoria has been found to be a traditionally important medicinal plant, it has not been reported so far to have wound healing effect in traditional systems of medicine. This is the first study to be reported where extracts of leaves and fruits of Morinda tinctoria were studied along with pure oleuropein (Assay 80\%) a minor iridoid and a major component of Morinda tinctoria on the wound healing activity. Our results show that pure oleuropein at both $1.5 \%(\mathrm{w} / \mathrm{w})$ and $3 \%(\mathrm{w} / \mathrm{w})$ was inferior to crude fruit extract in wound healing and in all the other associated physiological changes. This indicates that other components present in the extract act synergistically along with oleuropein in wound healing.

\section{Acknowledgement:-}

The authors would like to thank Dr. K.V. Krishnamurthy for his help in improving this manuscript and also like to thank Dr.Jyothi and Dr.Sridhar, Srimad Andavan Arts and Science college, Trichy, Tamil Nadu for providing /helping to carry out the in vivo animal studies.

\section{Conflict Of Interest:-}

The authors do not have any conflict of interest.

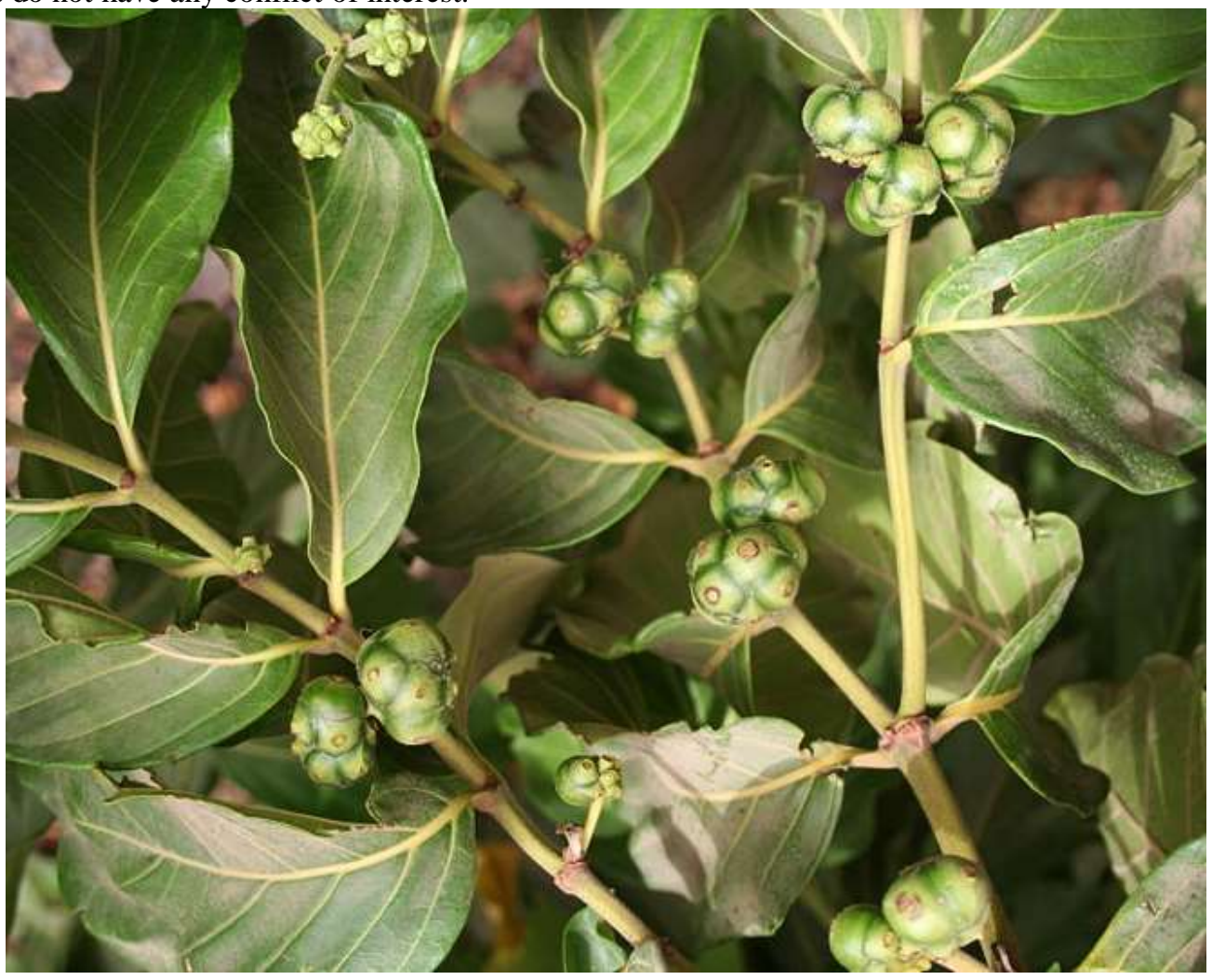

Fig.1:- Morinda tinctoria leaves and fruits. 


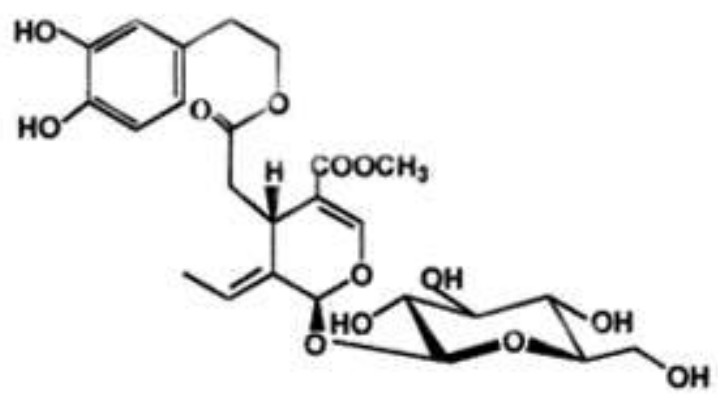

Fig. 2:- Structure of Oleuropein.

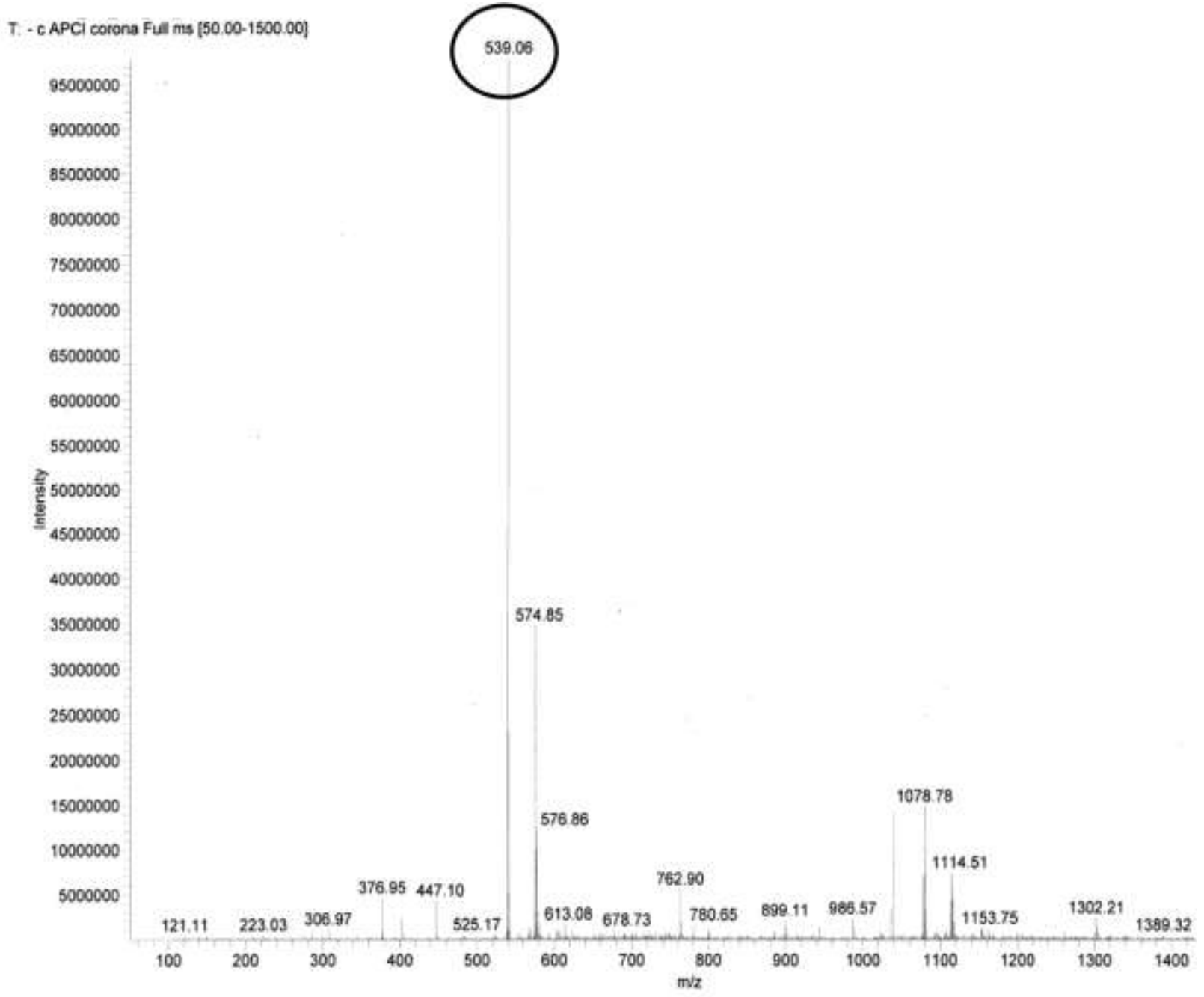

Fig.3:- LCMS fragmentation pattern of Oleuropein 


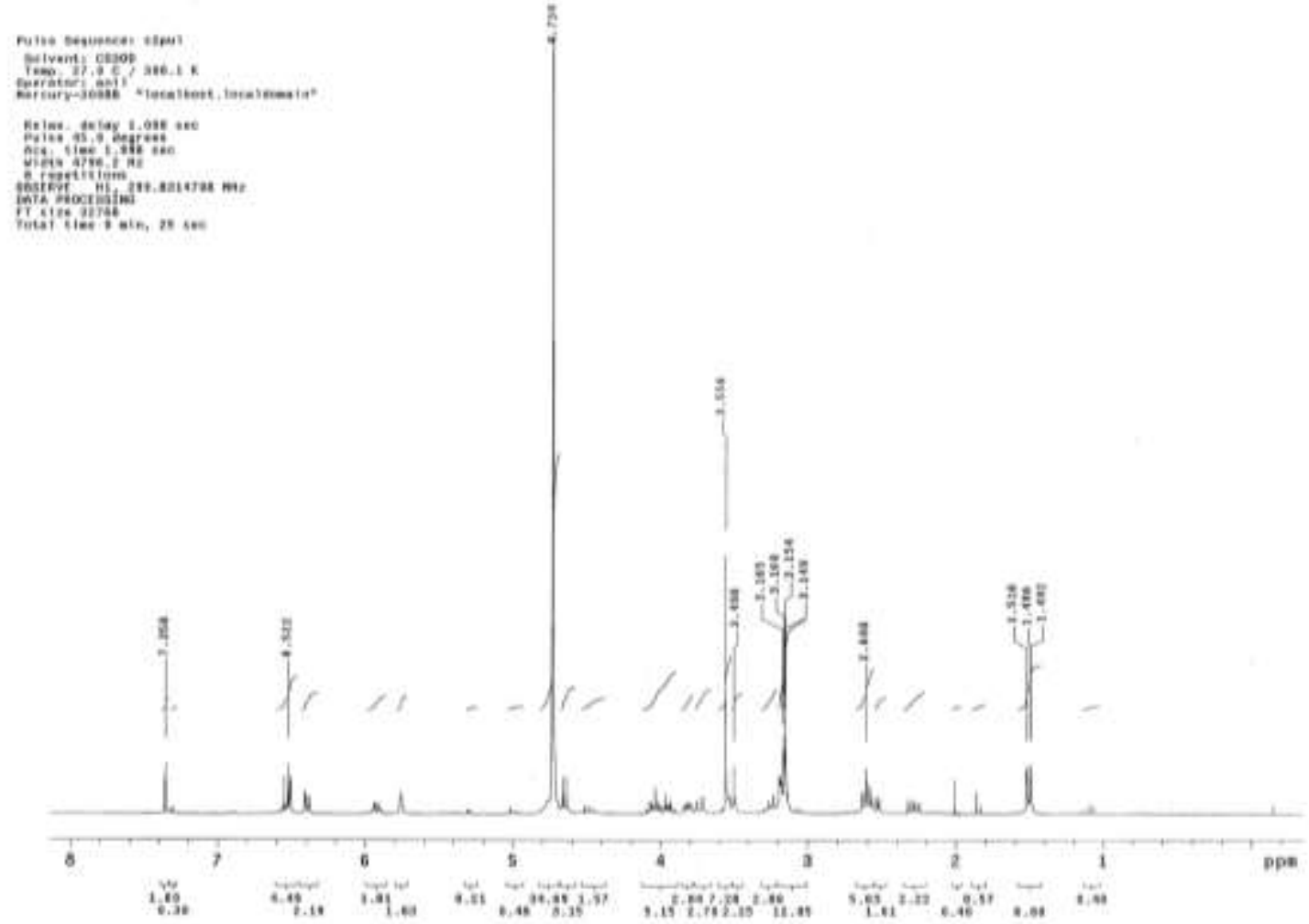

Fig.4:- ${ }^{1} \mathrm{H}$ NMR spectra of oleuropein.

คise sequenes szai

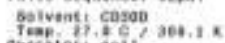

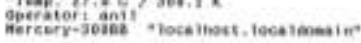

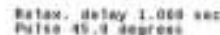

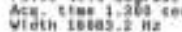

ays reptition:

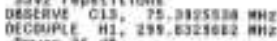

tomer as aid the

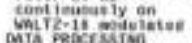

the norgentine o.s ux

Fotal tion

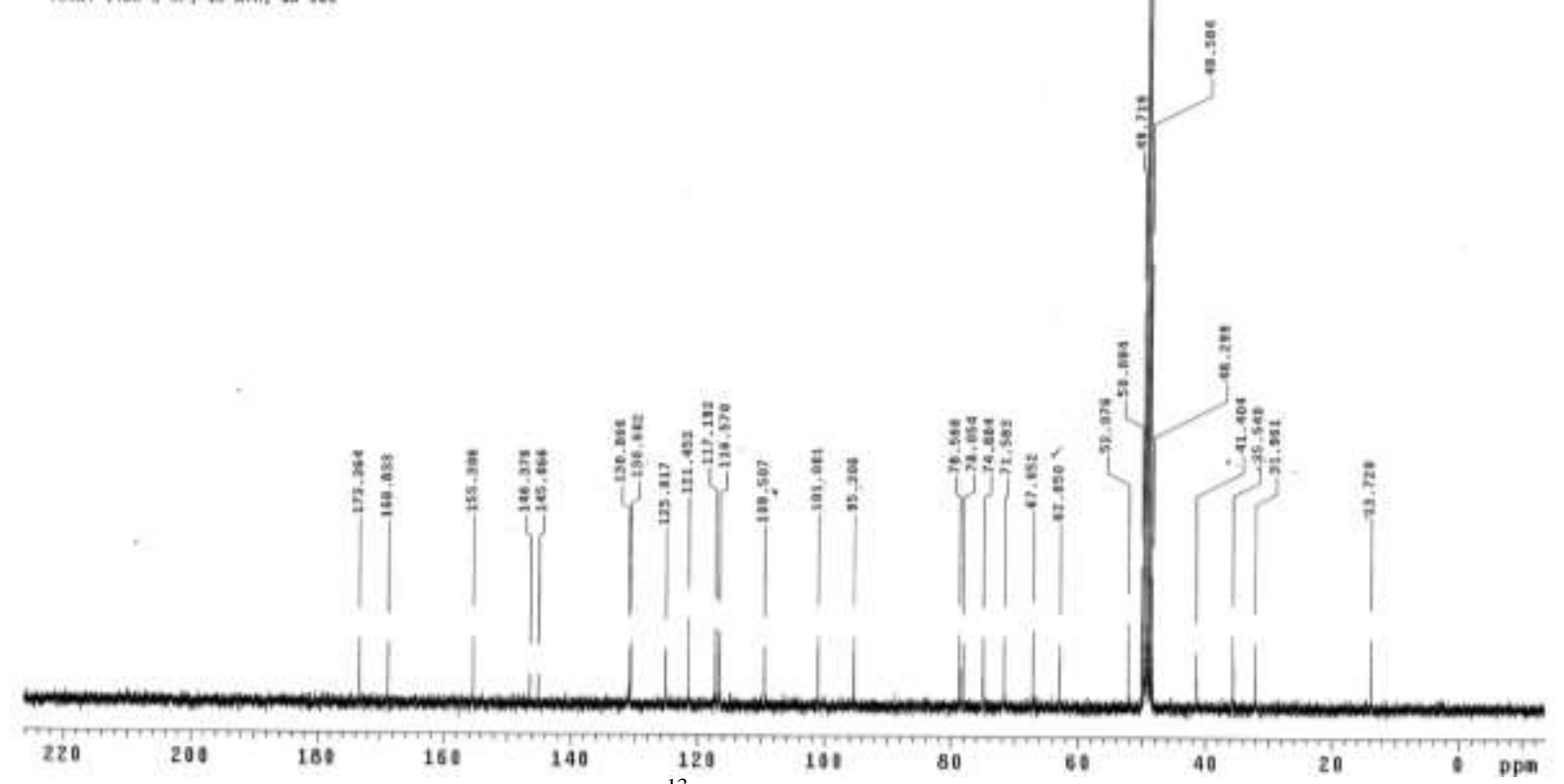

Fig.5:- ${ }^{13} \mathrm{C}$ Spectra of Oleuropein 


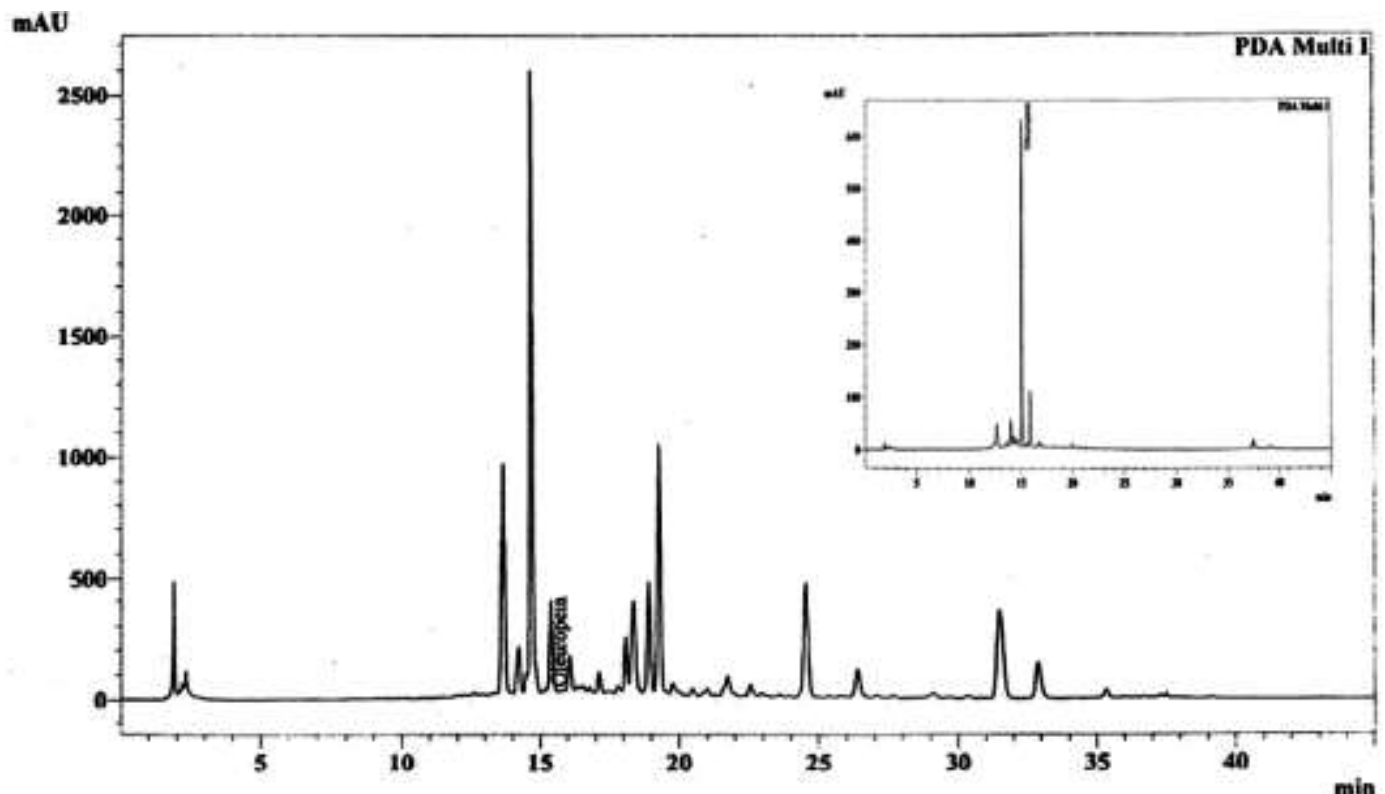

Fig.6:- HPLC chromatogram of MTLE and inside box shows the standard oleuropein peak.

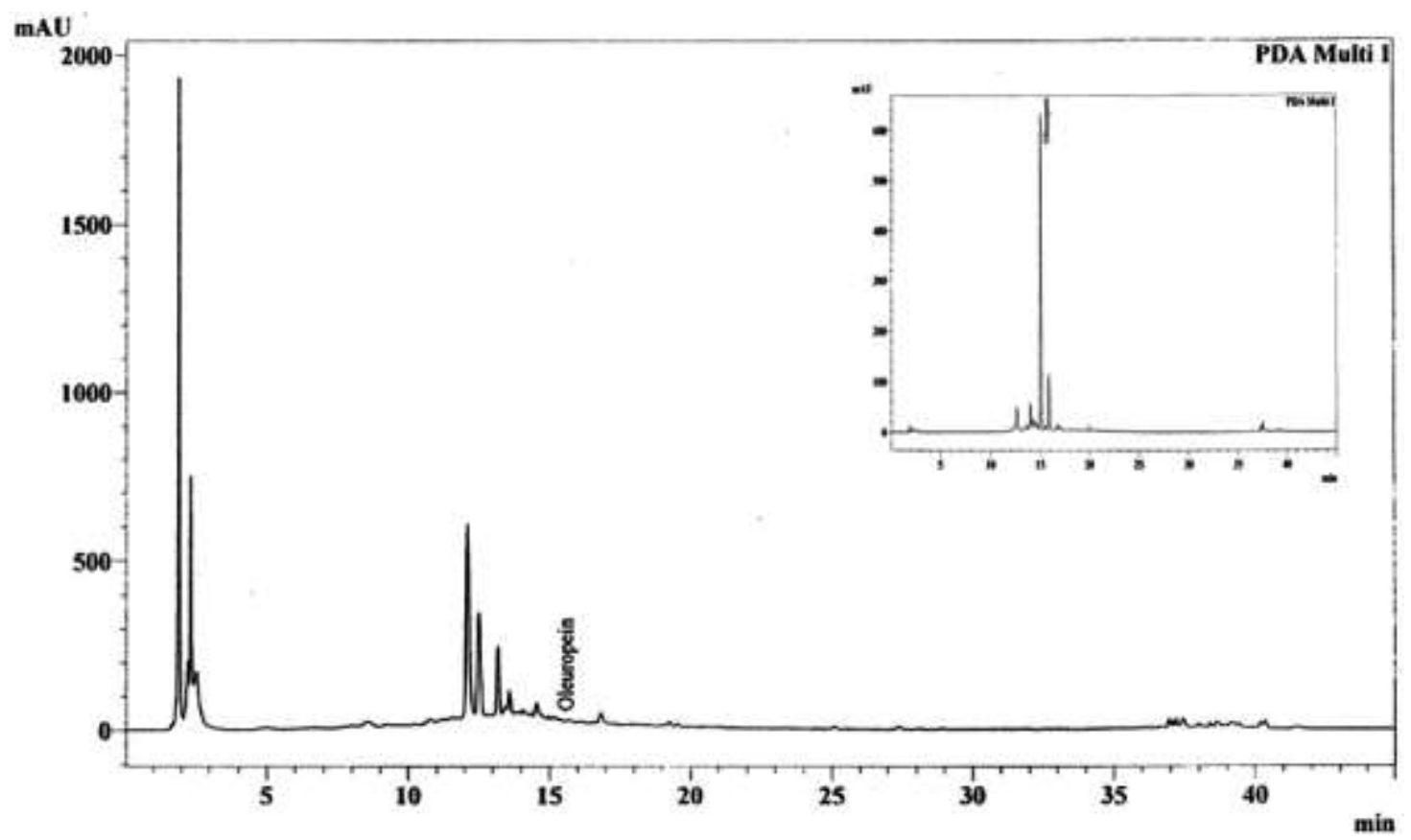

Fig.7:-HPLC chromatogram of MTFE and the inside image shows standard oleuropein peak. 

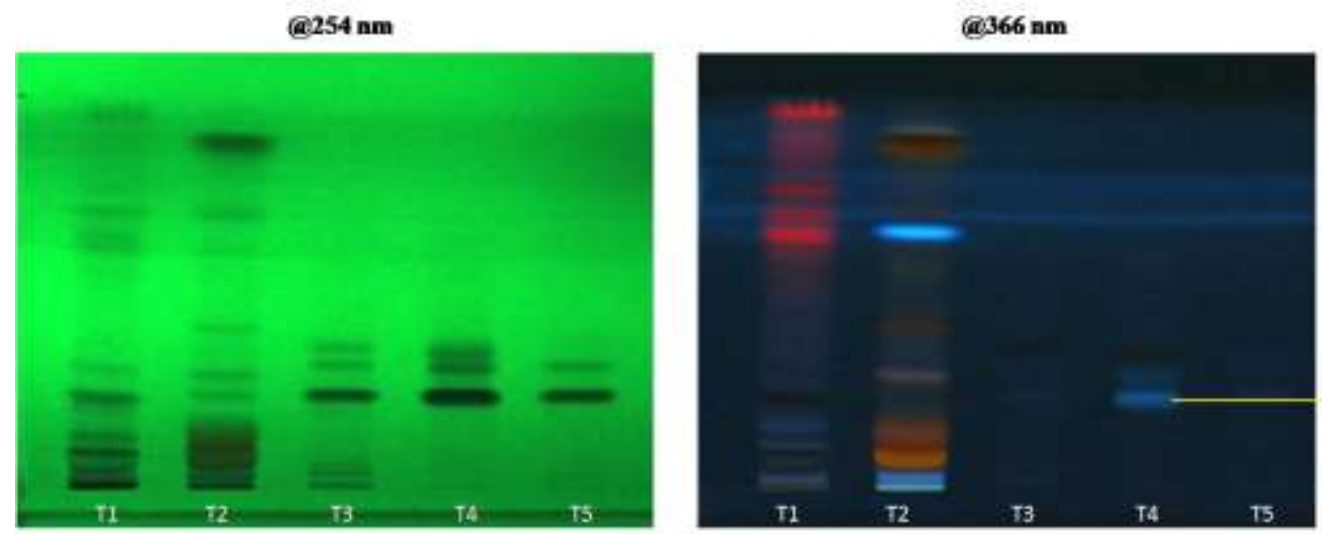

Olcuropein@0.25 Rf

Fig.8:- HPTLC fingerprinting profile of Morinda tinctoria with standard Oleuropein Track legends: T1- MTLE; T2-MTFE; T3 \& T4- isolated Oleuropein; T5- Reference standard Oleuropein.

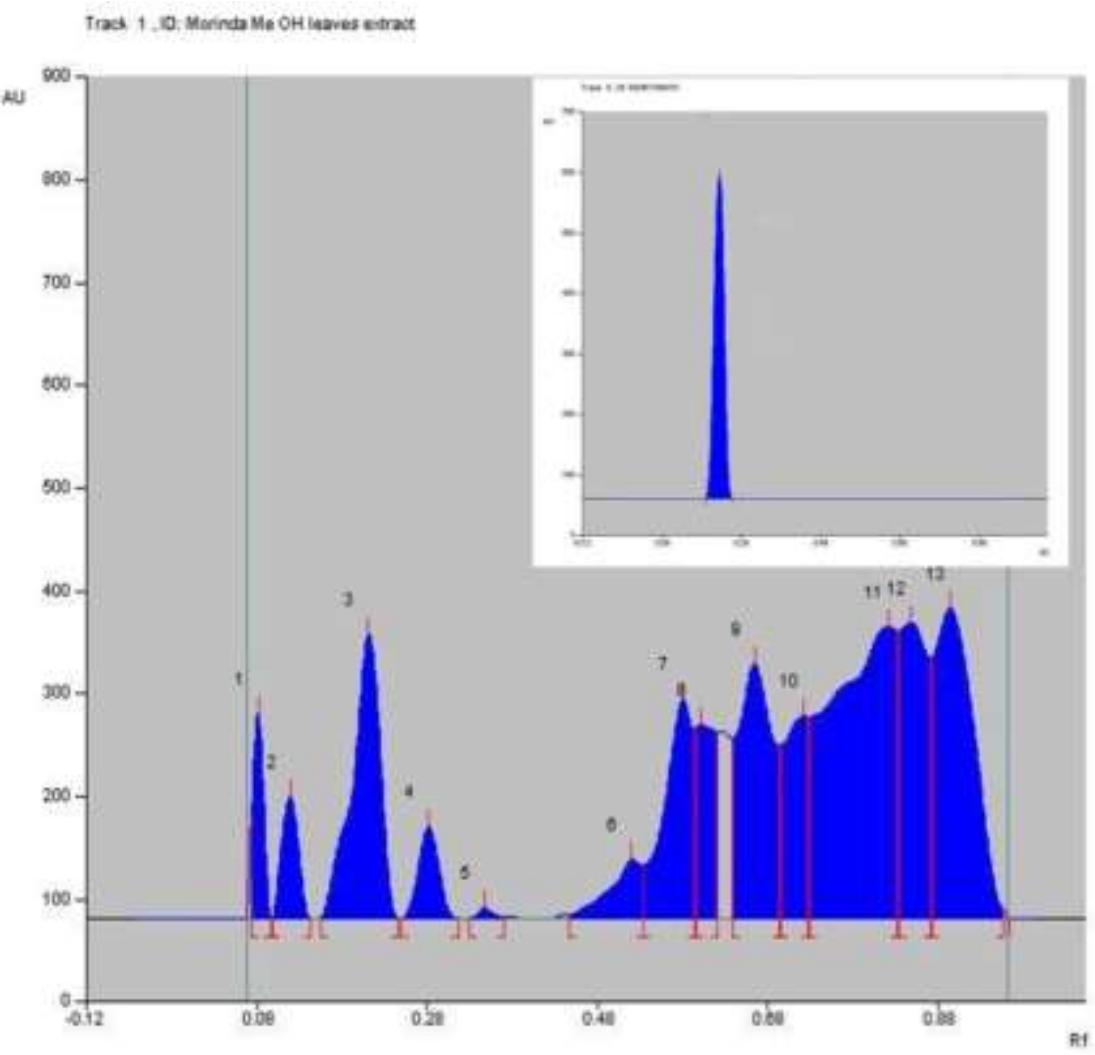

Fig.9:- HPTLC chromatogram of MTFE at 254nm and the inside box image of standard oleuropein. 


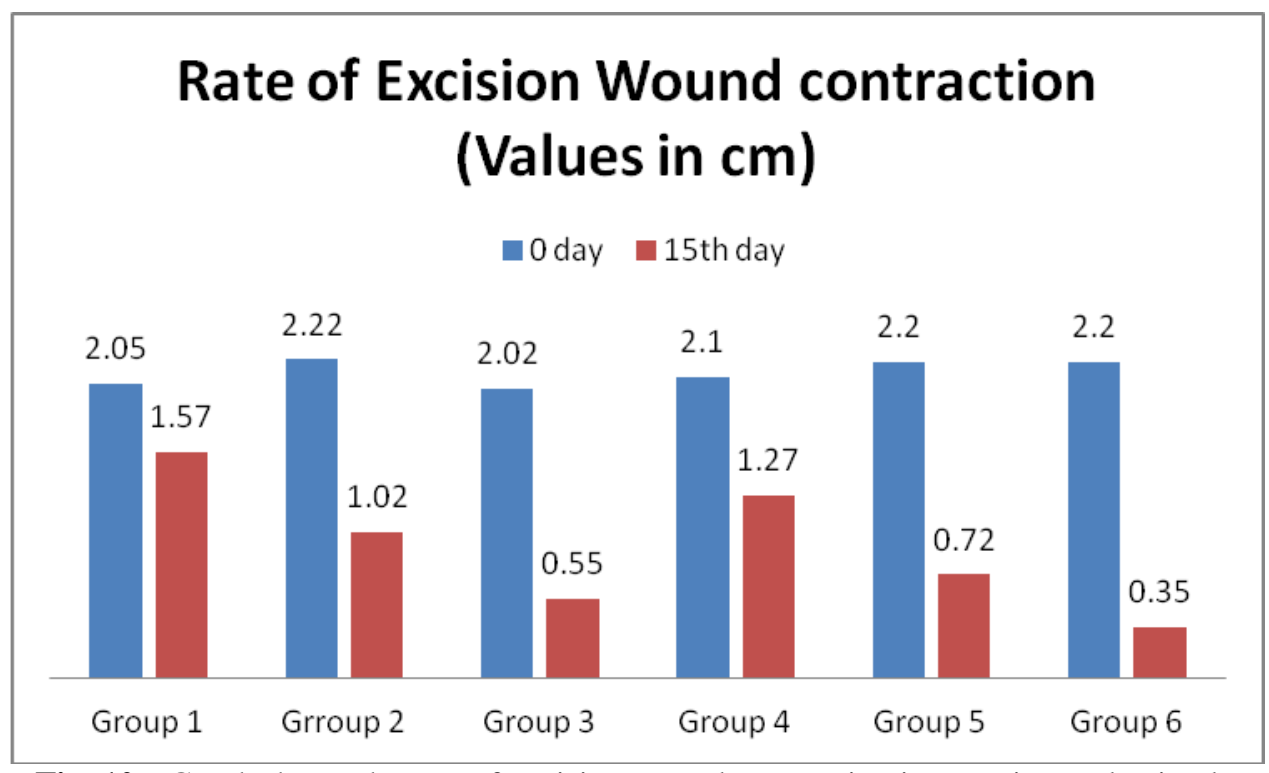

Fig. 10:- Graph shows the rate of excision wound contraction in experimental animals

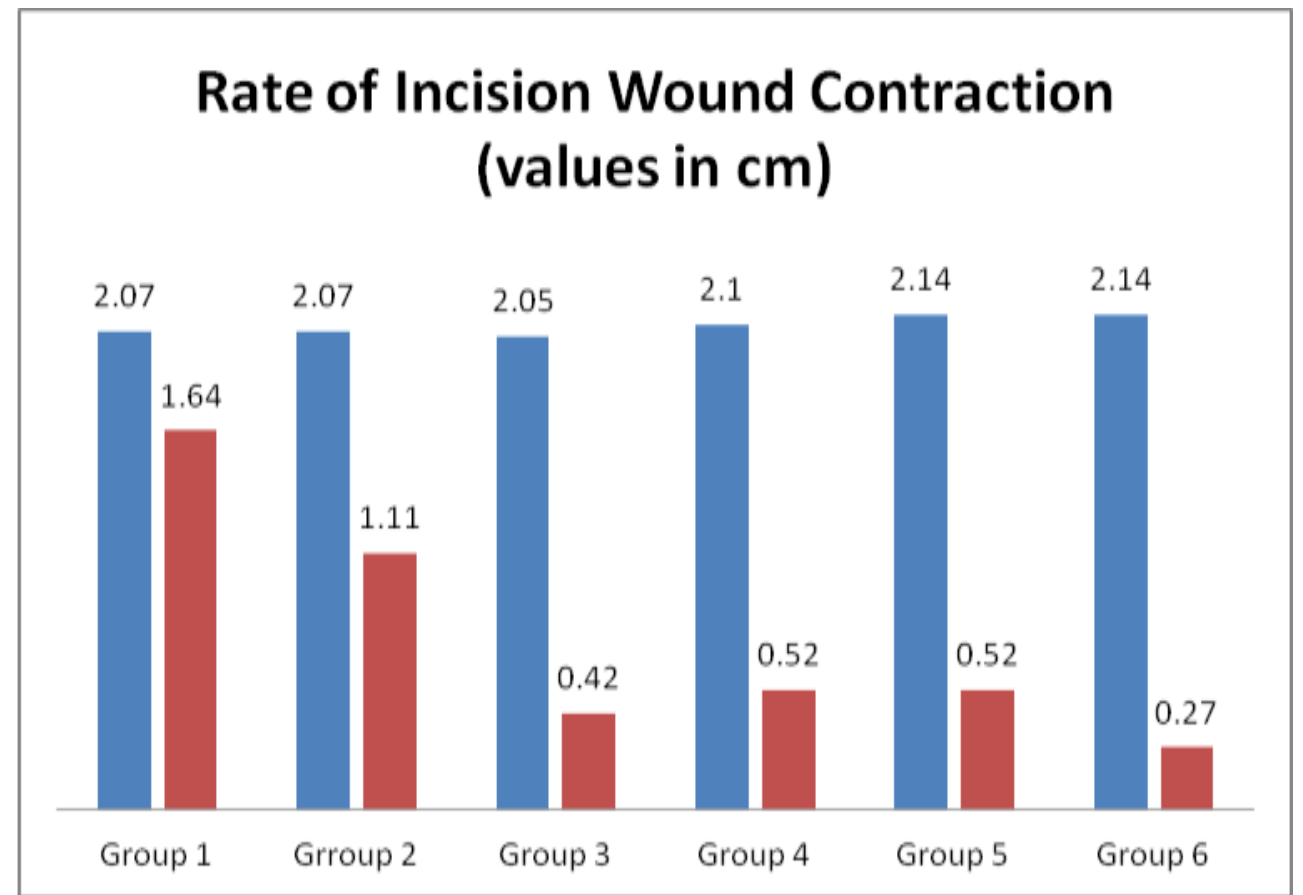

Fig. 11:- Graph shows the rate of incision wound contraction in experimental animals 

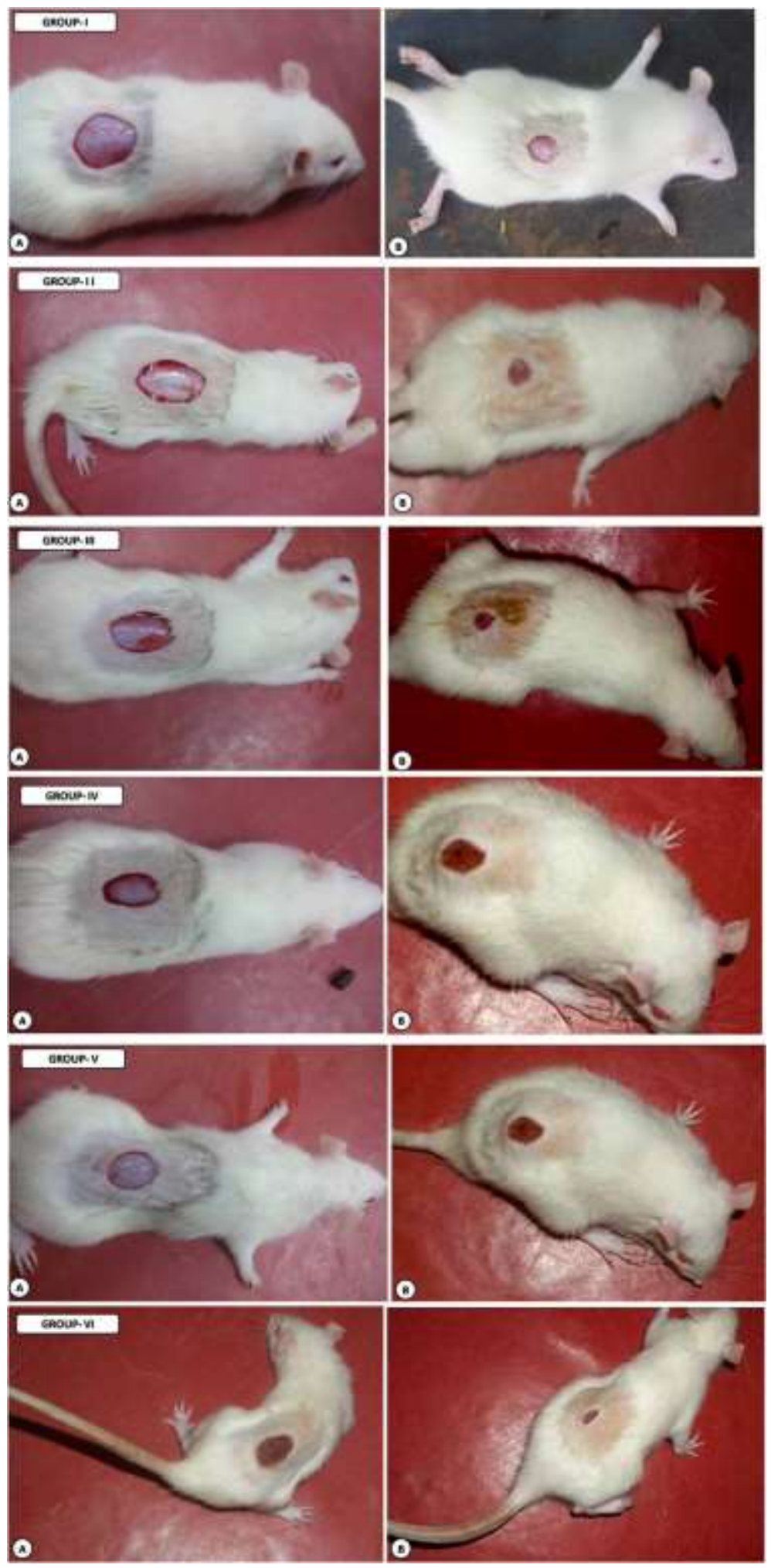

Fig. 12:- Wound healing potential of MTFE on excision wounded Wister rats. A: 0 day; B: $15^{\text {th }}$ day 


\section{Annexure A Supplementary Data}

Table No.1:- Tensile strength of skin in experimental animals.

\begin{tabular}{|l|l|l|l|}
\hline Groups & Tensile strength of skin $(\mathbf{g})$ & F Value & Result \\
\hline Group I & $213.50 \pm 1.15$ & NA & NA \\
\hline Group II & $306.33 \pm 2.09$ & 1513.41 & $\mathrm{p}<0.001^{* * *}$ \\
\hline Group III & $378.67 \pm 1.69$ & 6555.95 & $\mathrm{p}<0.001^{* * *}$ \\
\hline Group IV & $275.67 \pm 1.20$ & 1399.69 & $\mathrm{p}<0.001^{* * *}$ \\
\hline Group V & $341.67 \pm 2.39$ & 2337.39 & $\mathrm{p}<0.001^{* * *}$ \\
\hline Group VI & $396.83 \pm 1.17$ & 12551.87 & $\mathrm{p}<0.001^{* * *}$ \\
\hline
\end{tabular}

Note : *** - Sig. at $1 \%$ level

Table No. 2:- Granuloma weight in experimental animals.

\begin{tabular}{|c|c|c|c|}
\hline Groups & Granuloma weight (mg/100g) & F Value & Result \\
\hline Group I & $36.33 \pm 0.42$ & NA & NA \\
\hline Group II & $56.83 \pm 0.40$ & 1240.082 & $\mathrm{p}<0.001 * * *$ \\
\hline Group III & $72.50 \pm 0.50$ & 3057.727 & $\mathrm{p}<0.001 * * *$ \\
\hline Group IV & $46.83 \pm 0.48$ & 271.849 & $\mathrm{p}<0.001 * * *$ \\
\hline Group V & $63.67 \pm 0.42$ & 2101.250 & $\mathrm{p}<0.001 * * *$ \\
\hline Group VI & $83.33 \pm 0.61$ & 3976.200 & $\mathrm{p}<0.001 * * *$ \\
\hline
\end{tabular}

Note : *** - Sig. at $1 \%$ level

Table No. 3:- Platelet derived growth factor (PDGF)

\begin{tabular}{|l|l|l|l|}
\hline Groups & $\begin{array}{l}\text { Platelet derived growth } \\
\text { factor }(\mathbf{p g} / \mathbf{m l})\end{array}$ & F Value & Result \\
\hline Group I & $6.25 \pm 0.38$ & NA & NA \\
\hline Group II & $22.17 \pm 0.40$ & 825.362 & $\mathrm{p}<0.001 * * *$ \\
\hline Group III & $20.67 \pm 0.61$ & 396.936 & $\mathrm{p}<0.001 * * *$ \\
\hline Group IV & $19.83 \pm 0.40$ & 601.109 & $\mathrm{p}<0.001 * * *$ \\
\hline Group V & $17.83 \pm 0.40$ & 437.127 & $\mathrm{p}<0.001 * * *$ \\
\hline Group VI & $29.83 \pm 0.60$ & 1097.110 & $\mathrm{p}<0.001 * * *$ \\
\hline
\end{tabular}

Table No. 4:- TNF - alpha in experimental animals.

\begin{tabular}{|l|l|l|l|}
\hline Groups & TNF - Alpha $(\mathbf{p g} / \mathbf{m l})$ & F Value & Result \\
\hline Group I & $191.79 \pm 1.52$ & NA & NA \\
\hline Group II & $112.99 \pm 0.67$ & 2253.426 & $\mathrm{p}<0.001^{* * *}$ \\
\hline Group III & $90.77 \pm 0.58$ & 3859.304 & $\mathrm{p}<0.001^{* * *}$ \\
\hline Group IV & $122.79 \pm 0.73$ & 1673.951 & $\mathrm{p}<0.001^{* * *}$ \\
\hline Group V & $104.33 \pm 0.42$ & 3073.829 & $\mathrm{p}<0.001^{*} * *$ \\
\hline Group VI & $104.10 \pm 0.88$ & 2489.418 & $\mathrm{p}<0.001^{*} * *$ \\
\hline
\end{tabular}

Table No.5:- Levels of Hydroxyproline (HPR) in experimental animals

\begin{tabular}{|l|l|l|l|}
\hline Groups & $\begin{array}{l}\text { Hydroxyproline (mg/ g } \\
\text { tissue) }\end{array}$ & F Value & Result \\
\hline Group I & $31.56 \pm 1.78$ & NA & NA \\
\hline Group II & $46.67 \pm 1.24$ & 48.571 & $\mathrm{p}<0.001^{* * *}$ \\
\hline Group III & $62.22 \pm 0.66$ & 261.593 & $\mathrm{p}<0.001^{* * *}$ \\
\hline Group IV & $37.11 \pm 0.41$ & 9.273 & $\mathrm{p}<0.01^{* *}$ \\
\hline Group V & $50.67 \pm 0.49$ & 107.500 & $\mathrm{p}<0.001^{* * *}$ \\
\hline Group VI & $82.67 \pm 0.69$ & 718.750 & $\mathrm{p}<0.001^{* * *}$ \\
\hline
\end{tabular}

Note : *** - Sig. at $1 \%$ level;

\footnotetext{
** - Sig. at 5\% level
} 
Table No.6:- Hexosamine (HXA) in granulated tissue of experimental animals

\begin{tabular}{|l|l|l|l|}
\hline Groups & Hexosamine $(\mathbf{m g} / \mathbf{g}$ tissue $)$ & F Value & Result \\
\hline Group I & $3.19 \pm 0.32$ & NA & NA \\
\hline Group II & $7.05 \pm 0.32$ & 72.415 & $\mathrm{p}<0.001^{* * *}$ \\
\hline Group III & $9.33 \pm 0.26$ & 224.402 & $\mathrm{p}<0.001^{* * *}$ \\
\hline Group IV & $5.92 \pm 0.17$ & 57.065 & $\mathrm{p}<0.001^{* * *}$ \\
\hline Group V & $8.68 \pm 0.26$ & 181.988 & $\mathrm{p}<0.001^{* * *}$ \\
\hline Group VI & $12.46 \pm 0.17$ & 668.970 & $\mathrm{p}<0.001^{* * *}$ \\
\hline
\end{tabular}

Note : *** - Sig. at $1 \%$ level

Table No.7:- Levels of non antioxidant LPO enzyme in granulated tissue of experimental animals

\begin{tabular}{|l|l|l|l|}
\hline Groups & $\begin{array}{l}\text { LPO (nmol MDA/g } \\
\text { tissue) }\end{array}$ & F Value & Result \\
\hline Group I & $117.96 \pm 1.42$ & NA & NA \\
\hline Group II & $76.17 \pm 2.59$ & 200.726 & $\mathrm{p}<0.001^{* * *}$ \\
\hline Group III & $55.70 \pm 2.00$ & 645.904 & $\mathrm{p}<0.001^{* * *}$ \\
\hline Group IV & $82.03 \pm 2.66$ & 141.851 & $\mathrm{p}<0.001^{* * *}$ \\
\hline Group V & $63.23 \pm 3.86$ & 176.977 & $\mathrm{p}<0.001^{* * *}$ \\
\hline Group VI & $43.38 \pm 3.35$ & 420.478 & $\mathrm{p}<0.001^{* * *}$ \\
\hline
\end{tabular}

Note : $* * *$ - Sig. at $1 \%$ level

Table No.8:- Levels of non antioxidant GSH enzyme in granulated tissue of experimental animals

\begin{tabular}{|l|l|l|l|}
\hline Groups & GSH $(\boldsymbol{\mu g} / \mathbf{g}$ tissue $)$ & F Value & Result \\
\hline Group I & $1.4 \pm 0.08$ & NA & NA \\
\hline Group II & $2.1 \pm 0.33$ & 3.544 & $\mathrm{p}>0.01^{\mathrm{NS}}$ \\
\hline Group III & $4.0 \pm 0.28$ & 79.080 & $\mathrm{p}<0.001^{* * *}$ \\
\hline Group IV & $2.4 \pm 0.38$ & 6.786 & $\mathrm{p}<0.01^{* *}$ \\
\hline Group V & $3.7 \pm 0.40$ & 32.216 & $\mathrm{p}<0.001^{* * *}$ \\
\hline Group VI & $5.5 \pm 0.54$ & 54.237 & $\mathrm{p}<0.001^{* * *}$ \\
\hline
\end{tabular}

Note : *** - Sig. at $1 \%$ level; $* *$ - Sig. at $5 \%$ level; NS - Not Significant

Table No. 9:- Levels of antioxidant SOD enzyme in granulated tissue of experimental animals

\begin{tabular}{|l|l|l|l|}
\hline Groups & SOD $(\mathbf{U} / \mathbf{m g}$ protein) & F value & Result \\
\hline Group I & $3.81 \pm 0.25$ & NA & NA \\
\hline Group II & $5.37 \pm 0.38$ & 17.150 & $\mathrm{p}<0.001^{* * *}$ \\
\hline Group III & $9.05 \pm 2.05$ & 9.630 & $\mathrm{p}<0.01^{* *}$ \\
\hline Group IV & $5.12 \pm 0.45$ & 9.543 & $\mathrm{p}<0.01^{* *}$ \\
\hline Group V & $8.76 \pm 0.75$ & 59.223 & $\mathrm{p}<0.001^{* * *}$ \\
\hline Group VI & $11.10 \pm 0.92$ & 88.377 & $\mathrm{p}<0.001^{* * *}$ \\
\hline
\end{tabular}

Note $: *$ - Sig. at $1 \%$ level

Table No.10:- Levels of antioxidant CAT enzyme in granulated tissue of experimental animals

\begin{tabular}{|l|l|l|l|}
\hline Groups & CAT $($ U/mg protein) & F value & Result \\
\hline Group I & $3.80 \pm 0.81$ & NA & NA \\
\hline Group II & $7.33 \pm 0.54$ & 13.183 & $\mathrm{p}<0.001^{* * *}$ \\
\hline Group III & $9.69 \pm 0.47$ & 39.533 & $\mathrm{p}<0.001^{* * *}$ \\
\hline Group IV & $7.20 \pm 0.57$ & 11.757 & $\mathrm{p}<0.001^{* * *}$ \\
\hline Group V & $9.20 \pm 0.49$ & 32.377 & $\mathrm{p}<0.001^{* * *}$ \\
\hline Group VI & $11.95 \pm 0.45$ & 77.605 & $\mathrm{p}<0.001^{* * *}$ \\
\hline
\end{tabular}

Note : $*$ Sig. at $1 \%$ level

Table No.11:- Levels of antioxidant GPX enzyme in granulated tissue of experimental animals

\begin{tabular}{|l|l|l|l|}
\hline Groups & GPX $(\mathbf{U} / \mathbf{m g}$ protein) & F value & Result \\
\hline Group I & $2.04 \pm 0.19$ & NA & NA \\
\hline
\end{tabular}




\begin{tabular}{|l|l|l|l|}
\hline Group II & $3.96 \pm 0.11$ & 74.221 & $\mathrm{p}<0.001 * * *$ \\
\hline Group III & $7.53 \pm 0.12$ & 574.901 & $\mathrm{p}<0.001 * * *$ \\
\hline Group IV & $3.83 \pm 0.09$ & 69.424 & $\mathrm{p}<0.001 * * *$ \\
\hline Group V & $7.54 \pm 0.08$ & 692.357 & $\mathrm{p}<0.001 * * *$ \\
\hline Group VI & $7.74 \pm 0.11$ & 655.009 & $\mathrm{p}<0.001 * * *$ \\
\hline
\end{tabular}

Note : * Sig. at $1 \%$ level

Table No.12:- Levels of serum ascorbic acid in experimental animals

\begin{tabular}{|l|l|l|l|}
\hline Groups & Ascorbic Acid (mg/dl) & F value & Result \\
\hline Group I & $1.01 \pm 0.04$ & NA & NA \\
\hline Group II & $2.06 \pm 0.07$ & 184.573 & $\mathrm{p}<0.001^{* * * *}$ \\
\hline Group III & $2.84 \pm 0.12$ & 226.845 & $\mathrm{p}<0.001^{*} * *$ \\
\hline Group IV & 182.319 & $\mathrm{p}<0.001^{* * *}$ \\
\hline Group V & $2.04 \pm 0.07$ & 399.376 & $\mathrm{p}<0.001^{* * *}$ \\
\hline Group VI & $2.91 \pm 0.09$ & 391.452 & $\mathrm{p}<0.001^{* * *}$ \\
\hline
\end{tabular}

Table No.13:- Levels of nucleic acid content in granulated tissue of experimental animals

\begin{tabular}{|l|l|l|l|}
\hline Groups & DNA (mg/g of tissue) & F value & Result \\
\hline Group I & $4.54 \pm 0.33$ & & \\
\hline Group II & $10.17 \pm 0.79$ & 43.372 & $\mathrm{p}<0.001^{* * *}$ \\
\hline Group III & $14.38 \pm 0.95$ & 96.772 & $\mathrm{p}<0.001^{* * *}$ \\
\hline Group IV & $9.50 \pm 0.81$ & 32.415 & $\mathrm{p}<0.001^{* * *}$ \\
\hline Group V & $13.03 \pm 0.95$ & 71.715 & $\mathrm{p}<0.001^{* * *}$ \\
\hline Group VI & $15.78 \pm 0.85$ & 152.888 & $\mathrm{p}<0.001^{* * *}$ \\
\hline
\end{tabular}

Table No.14:- Levels of ribonucleic acid content in granulated tissue of experimental animals

\begin{tabular}{|l|l|l|l|}
\hline Groups & RNA (mg/g of tissue) & F value & Result \\
\hline Group I & $7.4 \pm 0.4$ & $\mathrm{NA}$ & NA \\
\hline Group II & $11.7 \pm 0.1$ & 86.533 & $\mathrm{p}<0.001^{* * *}$ \\
\hline Group III & $14.3 \pm 0.1$ & 216.903 & $\mathrm{p}<0.001^{* * *}$ \\
\hline Group IV & $11.2 \pm 0.5$ & 32.348 & $\mathrm{p}<0.001^{* * *}$ \\
\hline Group V & $13.5 \pm 0.2$ & 143.417 & $\mathrm{p}<0.001^{* * *}$ \\
\hline Group VI & $19.7 \pm 0.3$ & 524.879 & $\mathrm{p}<0.001^{* * *}$ \\
\hline
\end{tabular}

\section{References:-}

1. Pal, DC. and Jain, SK. (1998): Tribal Medicine. Naya Prokash, Kolkata, India.

2. Nadkarni, AK. (1998): Indian Meteria Medica, Popular Prakashan,138-39.

3. Mathivanan, N. and Surendiran, G. (2006): Chemical properties and biological activities of Morinda spp. Proceedings of First National Symposium on Noni Research, October 7-8, 1-21.

4. Jayasinghe, ULB., Jayasooriya, CP., Bandara, BMR., Ekanayake, SP., Merlini, L. and assante, G. (2002): Antimicrobial activity of some Srilankan Rubiaceae and Meliaceae. Fitoterapia; 73: 424-427.

5. Kumarasan TP. and Saravanan A. (2009): Anticonvulsant activity of Morinda tinctoria Roxb. African Journal of Pharmacy Pharmacology; 3: 63- 65.

6. Deepti, K., Umadevi, P., Vijayalakshmi, G., Polarao, BV. (2012): Antimicrobial Activity and Phytochemical Analysis of Morinda tinctoria Roxb. Leaf Extracts. Asian Pacific journal of tropical Biomedicine; S1440-1442.

7. Kolli, D., Amperayani, KR. and Parimi, U, (2015): Total Phenolic content and antioxidant activity of morinda tinctoria leaves Indian Journal Pharmaceutical Sciences.;77 : 226-230.

8. Rao, CM., George, KM., Bairy KL and Somayaji SN. (2000): An apprantial of the healing profiles of oral and external (gel) Metronidazole on partial thickness burn wounds, Indian Journal of Pharmacology., 32: 282.

9. Saha, K., Mukherjee, PK., Das, J., Pal, M. and Saha, BP. (1997): Wound healing activity of Leucas lavandulaefolia Rees. Journal of Ethnopharmacology., 56:139-144.

10. Lee, KH. (1968): Studies on the mechanism of action of salicylates III. Effect of vitamin A on wound healing retardation of aspirin. Journal of Pharmacological Sciences., 57: 1238-40.

11. Woessner JF Jr. (1961): The determination of hydroxyproline in tissue and protein samples containing small proportions of this imino acid. Archives of Biochemistry and Biophysics., 93:440-7. 
12. Wagner, WD. (1979): A More sensitive assay discriminating galactosamine and glucosamine in mixtures. Analytical Biochemistry., 94:394-6.

13. Giles, K. and Myers, A. (1965): An improved diphenylamine method for the estimation of deoxyribonucleic acid. Nature; 206, 93.

14. Yoichi, Endo. (1970): A Simultaneous estimation method of DNA and RNA by the orcinol reaction and a study on the reaction mechanism. Journal of Biochemistry., 67(5): 629-633.

15. Kadowaki, E., Yoshida, Y., Baba, N., Nakajima, S. (2003): Feeding Stimulative Activity of Steroidal and Secoiridoid Glucosides and their Hydrolysed Derivatives towards the olive Weevil (Dyscerus perforatus). Verlag der Zeitschrift tur Naturforschung., 58c: 441-445.

16. Arunachalam, KD., Kuruva, JK., Hari, S., Annamalai, SK. and Baskaran KV. (2015): HPTLC Finger print analysis and Phytochemical Investigation of Morinda tinctoria Roxb. Leaf extracts by HPLC and GS MS. International Journal of Pharmacy and Pharmaceutical Sciences., 7: 360-366.

17. Sait, II., Harindran, J., Vahab, A., Jeena, JL., Nasli, S. and John, J. (2014): Potential hepatoprotective effect and anti oxidant role of methanol extract of Morinda tinctoria in carbon tetra chloride induced hepatotoxicity in Albino rats, International Journal of Pharmaceutics., 4:363-368

18. Swamy, HMK., Krishna, V., Shankamurthy, K., Rahiman, BA., Mankani, KL., Mahadevan, KM., Harish, BG. and Naika, HR. (2006): Wound healing activity of embelin isolated from the ethanol extract of leaves of Embelia ribes Burm. Journal of Ethnopharmacology., 109: 529-534.

19. Stadelmann, WK., Digenis, AG. And Tobin, GR. (1998): Physiology and healing dynamics of chronic cutaneous wounds. The American Journal of Surgery., 176: 2A Suppl: 26S-38S.

20. Udupa, AL., Kulkarni, DR. and Udupa, SL. (1995): Effect of Tridax procumbens extracts on wound healing. International Journal of Pharmacognosy., 33: 37-40.

21. Moyer, KE., Saggers, GC., Allison, GM., Mackay, DR. and Ehrlich, HP. (2002): Effects of interleukin-8 on granulation tissue maturation. Journal of Cellular Physiology., 193: 173-179.

22. Pierce, GF., Mustoe, TA., Altrock, BW., Deuel, TF., Thomason, A.(1991): Role of Platelet derived growth factor in wound healing. Journal of Cellular Biochemistry.,45:319-326.

23. Rapala, K. The effect of tumor necrosis factor-alpha on wound healing. (1996): An experimental study. Annales chirurgiae et gynaecologiae Supplementum., 211: 1-53.

24. Hayouni, EA., Miled, K., Boubaker, S., Bellasfar, Z., Abedrabba, M., Iwaski, H., Oku H, Matsui, T., Limam, F., and Hamdi, M. (2011): Hydroalcoholic extract based-ointment from Punica granatum L. peels with enhanced in vivo healing potential on dermal wounds.Phytomedicine.,18:976-984.

25. Chigurupati, S., Mughal, MR., Okun, E., Das, S., Kumar, A., McCaffery, M., Seal, S. and Mattson, MP. (2013): Effects of cerium oxide nanoparticles on the growth of keratinocytes, fibroblasts and vascular endothelial cells in cutaneous wound healing. Biomaterials.,34: 2194-2201.

26. Gonçalves, RV., Novaes, RD., Sarandy, MM., Damasceno. EM., Matta, SLP., de Gouveia, NM., Freitas, MB. and Espindola FS.(2016): 5o-Dihydrotestosterone enhances wound healing in diabetic rats. Life Sciences., 152; 67-75.

27. Pratibha, R., Sameer, R., Rataboli, PV., Bhiwgade, DA. and Dhume, CY. (2016): Enzymatic studies of cisplatin induced oxidative stress in hepatic tissue of rats. The European Journal of Pharmacology.,532: 290-293.

28. Seguí, J., Gironella, M., Sans, M., Granell, S., Gil, F., Gimeno, M., Coronel, P., Piqué, JM. and Panés J.(2004): Superoxide dismutase ameliorates TNBS-induced colitis by reducing oxidative stress, adhesion molecule expression, and leukocyte recruitment into the inflamed intestine. Journal of Leukocyte Biology.,76:537-44.

29. Gorman, CM., Moffat, LF. and Howard BH.(1982): Recombinant genomes which express chloramphenicol acetyltransferase in mammalian cells. Molecular and cellular Biology., 2 : 1044-1051.

30. Ran, Q., Liang, H., Ikeno, Y., Qi, W., Prolla, TA., Roberts, LJ., Wolf, N., Van Remmen, H. and Richardson, A.(2007): Reduction in glutathione peroxidase 4 increases life span through increased sensitivity to apoptosis. The Journals of Gerontology. Series A, Biological Sciences and Medical Sciences., 62: 932-42. 